\title{
Directions in vehicle efficiency and emissions
}

\begin{abstract}
This paper provides a general review of light-duty (LD) and heavy-duty (HD) regulations, engine technology, and key emission control strategies. The US is placing a stronger emphasis on laboratory emissions, and the LD regulations are about an order of magnitude tighter than Euro 6, but Europe is focusing on real-world reductions. The California HD low-NO regulation is advancing and may be proposed in 2017/18 for implementation in 2023+. The second phase of US HD greenhouse gas regulations propose another 25-30\% tightening beyond Phase 1, beginning in 2021. LD and HD engine technology continues showing marked improvements in engine efficiency. LD gasoline concepts are closing the gap with diesel. HD engines are demonstrating more than 50\% BTE using methods that can reasonably be commercialized. $L D$ and HD diesel $N O_{x}$ technology trends are also summarized. $N O_{x}$ storage catalysts and SCR combinations are the lead approach to meeting the LD regulations. Numerous advanced $N O_{x}$ technologies are being evaluated and some promise for meeting the California HD low NO targets. Oxidation catalysts are improved for both diesel and methane oxidation applications. Gasoline particulate filters (GPF) are the lead approach to reducing particles from gasoline direct injection (GDI) engines. They reduce PAH emissions, and catalyzed versions can be designed for low back pressure. Regeneration largely occurs during hot decelerations.
\end{abstract}

Key words: greenhouse gases, vehicle emissions, regulations, engines, aftertreatment, $N O_{x}$, diesel oxidation catalyst, selective catalytic reduction, diesel particulate filter, gasoline particulate filter

\section{Introduction}

The challenges are significant in reducing vehicular criteria pollutants and greenhouse gases to meet tightening regulations around the world. Multitudes of papers and presentations are given annually to advance the understanding and technologies.

This paper focuses on recent key developments related to emissions for both diesel and gasoline engines in the automotive and heavy-duty markets. It begins with an overview of the major regulatory developments covering criteria pollutants and $\mathrm{CO}_{2}$. Then, a high-level review is provided of engine technologies, starting with light-duty gasoline and diesel engines, and then heavy-duty diesel engines. In this section, only broad developments are covered with the intent of summarizing the directions and emissions challenges for exhaust technologies. Next, the paper covers lean $\mathrm{NO}_{x}$ control, oxidation catalysts, diesel and gasoline PM filters, and closes with representative papers on gasoline emission control.

This review is not intended to be all-encompassing and comprehensive. Representative papers and presentations were chosen that provide examples of new, key developments and direction.

\section{Regulations}

Figure 1 shows the relative light-duty (LD) gasoline vehicle tailpipe non-methane hydrocarbon (NMHC) and $\mathrm{NO}_{\mathrm{x}}$ regulations for representative regions around the world. The emerging US Tier 3 regulations, which started phase-in in California (regulation LEV3) in 2015, are the tightest in the world, and are $85 \%$ to $90 \%$ (for diesel) tighter than the current Euro 6 regulations. The US also has much tighter durability requirements of 240,000 km versus $160,000 \mathrm{~km}$ for Europe. For the first time, China is proposing deviating from the European regulations with their China $6 \mathrm{~b}$ regulations, which are $1 / 3$ of the Euro 6 standards, proposed for 2023. Given the relative size and dominance of these two markets, it seems likely the rest of the world will eventually follow. Additionally, further tightening in the US is possible with California recently laying out a regulation roadmap for $2025+$ suggesting converting the fleet average $\mathrm{NMHC}+\mathrm{NO}_{x}$ emissions of the $18 \mathrm{mg} / \mathrm{km}$ shown in the figure to a cap.

Europe also sees a need to reduce vehicular emissions, but is emphasizing tighter enforcement of current regulations by incorporating a real-driving emissions (RDE) regulation for $\mathrm{NO}_{\mathrm{x}}$ from light-duty diesel (LDD) and particles from gasoline direct injection (GDI) vehicles. Implementation is scheduled to begin in September 2017 with emissions being measured on roads using portable emissions monitoring systems (PEMS). By 2021, the RDE effective emissions are expected to be similar to the dynamometer certification limit values, versus values that averaged $\sim 6 \mathrm{x}$ measured on 38 Euro 6 cars tested using the RDE protocol (1).

For heavy-duty (HD) vehicles, the Euro VI regulations allow $10 \mathrm{mg} / \mathrm{kWh} \mathrm{PM}$ (particle mass) and $460 \mathrm{mg} / \mathrm{kWh} \mathrm{NO}$ on the world-harmonized heavy-duty transient cycle. The US regulations are $30 \%$ looser on PM but about $40 \%$ tighter on $\mathrm{NO}_{\mathrm{x}}$ using the US transient cycle. Europe also added a particle number standard of $6 \times 10^{11}$ particles $/ \mathrm{kWh}$ on the transient cycle, essentially forcing the use of diesel particulate filters (DPF). Although not required to meet the PM regulation in the US, all heavy-duty trucks use DPFs to meet all aspects of the regulation. California is investigating further tightening the HD regulations by as much as an order of magnitude in the 2023-2027 timeframe, and the US EPA (Environmental Protection Agency) is considering following.

Shifting to greenhouse gases, Figure 2 shows a comparison of $\mathrm{LD} \mathrm{CO}_{2}$ regulations around the world [2]. In this case 


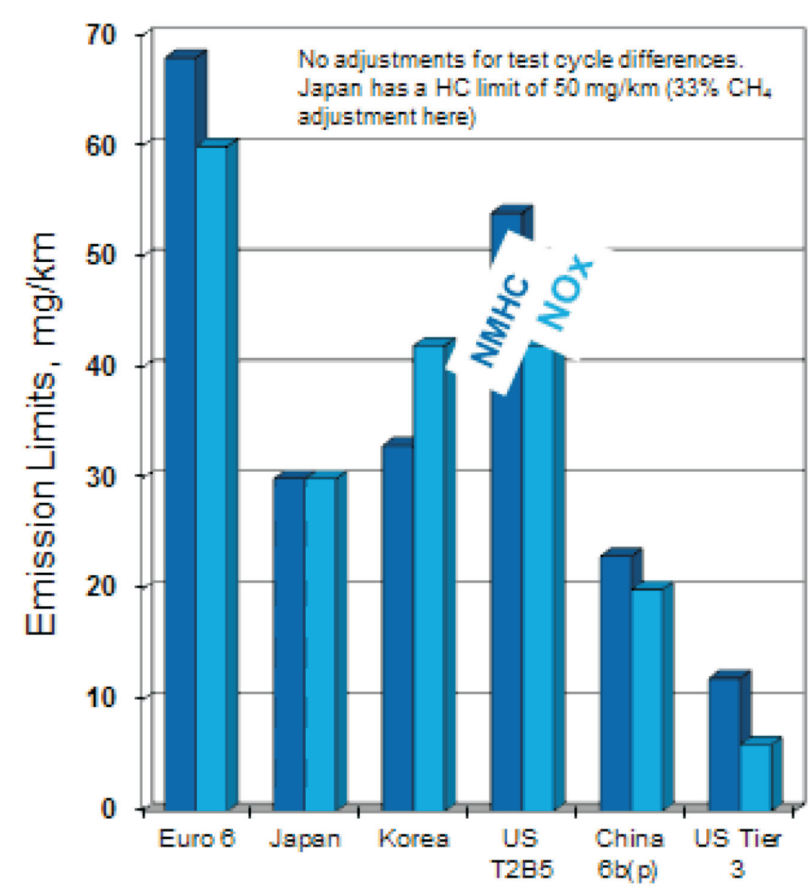

Figure 1. Relative comparison of key gasoline LD vehicle non-methane hydrocarbon (NMHC) and $\mathrm{NO}_{\mathrm{x}}$ emissions regulations for key world markets

Europe takes the lead, wherein the US generally harmonizes with a five-year delay. However, again in real-world driving the emissions improvements are different. European realworld $\mathrm{CO}_{2}$ emissions as indicated using fuel consumption records on 600,000 vehicles were compared to certification values measured on the NEDC (New European Drive Cycle) [3]. The study found that model 2001 cars were emitting about $8 \%$ more $\mathrm{CO}_{2}$ than indicated on the test cycle. But in 2014 this gap increased to $40 \%$, with virtually no real-world $\mathrm{CO}_{2}$ emissions improvements for models 2010 to 2014. The researchers attribute $75 \%$ of the 2014 gap to testing the vehicles on the dynamometer using the favorable end of allow-

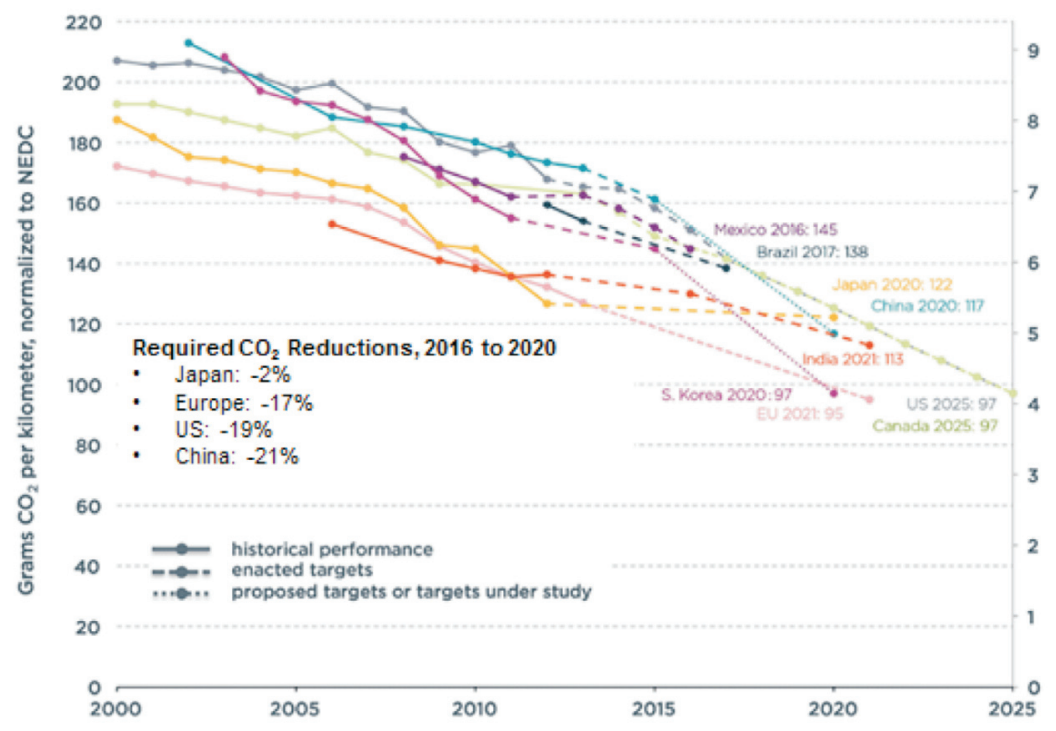

Fig. 2. Comparison of $\mathrm{LD} \mathrm{CO}_{2}$ regulations around the world [2] able tolerances and procedures during certification testing. In the US, one estimate [4] is that automakers will need to triple their annual rate of improvement in vehicle efficiency (traction energy/fuel energy; 22\% in 2015) from $0.3 \%$ per year to $0.9 \%$ per year to meet the 2025 regulations.

On the HD side, the final stage of the US Phase $1 \mathrm{HD}$ greenhouse regulation starts in 2017. The EPA (Environmental Protection Agency) finalized a Phase 2 rule that will build upon this and be phased in from 2021 through 2027 [5]. The main features of the rule are:

- Maintain separate engine and vehicle standards, but reweigh test cycles to better-reflect real-world operation. Engines should improve fuel consumption by $4-6 \%$ from 2017 to 2027.

- Regulate trailers using a computer model of technology options such as aerodynamics, rolling resistance, and weight reduction.

- Include transmissions using modeling or integrated powertrain testing.

- Improved vehicle simulation model to regulate vehicle technologies.

- 18 vocational vehicle categories.

- Chassis dyno confirmation of reductions for some classifications.

- Regulate natural gas emissions from the crankcase and LNG (liquid natural gas) tanks.

Total $\mathrm{CO}_{2}$ reductions from the large line-haul freight trucks and trailers is on the order of $25 \%$ from the 2017 Phase 1 baseline.

\section{Engine developments}

Figure 3 shows estimates of $\mathrm{CO}_{2}$ reductions, emissions issues, and the status of representative LD engine technologies, relative to the basic turbo-charged directinjection gasoline engine. Given the expense and market resistance to $\mathrm{EV}$ technologies (only $<5 \%$ hybrid market penetration 18 years after the first introduction), it seems reasonable that engine technology will be developed to the maximum practical potential and be combined with hybridization.

Figure 4 summarizes improvements and normalized cost of powertrain technologies to bring a Euro 5 platform to the EU and US $\mathrm{CO}_{2}$ standards of 2020-22 [6]. Gasoline engines are closing the $\mathrm{CO}_{2}$ gap with diesel. However, the incremental cost of the diesel improvements is considerably less than that of gasoline once a diesel powertrain investment is made. Also, hybridization is generally more expensive than engine improvements.

The impact of advanced engine concepts will affect exhaust gas temperatures, highlighting the challenge of increasing engine efficiency while reducing criteria pollutants. This can especially be problematic for diesel 
engines. Pischinger [7] nicely summarizes the relationship between time, fuel consumption reductions and exhaust gas temperatures for the 2 liter class engines at a medium load point. Post-turbo temperatures dropped a remarkable $220^{\circ} \mathrm{C}$ $\left(480^{\circ} \mathrm{C}\right.$ to $260^{\circ} \mathrm{C}$ ) from 2005 to 2015 while BSFC (brake specific fuel consumption) dropped $5 \%$.

\begin{tabular}{|c|c|c|c|}
\hline & $\mathrm{CO}_{2}$ Reduction & Emissions Issues & Status \\
\hline GDI base, turbo, stoich & 0 & PN & Implemented \\
\hline Cylinder de-activation & $5-8 \%$ & - & Implemented \\
\hline Homogeneous Lean SI & $5-10 \%$ & Lean NOx & Development \\
\hline HEV (additive to others) & $7-30 \%$ & - & Implemented \\
\hline $\begin{array}{l}\text { Downsize GDI, } 18 \rightarrow 24 \text { bar BMEP } \\
\text { high CR, Miller stoic }\end{array}$ & $10-15 \%$ & PN & Implementing \\
\hline$d-$ and $c-E G R$ & $10-15 \%$ & Cold start, controls & Implementing \\
\hline $\begin{array}{l}\text { CR 17, S/B 1.5, C-EGR, 2- } \\
\text { stage boost,stoich, Miller. }\end{array}$ & $15-20 \%$ & - & Adv Eng \\
\hline Lean-burn GDI & $10-20 \%$ & Lean NOx, PN & Implementing \\
\hline Light-duty diesel & $15-20 \%$ & Lean NOx & Implemented \\
\hline $\begin{array}{l}\text { GDI, Down Size (40\%), mHEV, } \\
\text { SChrg, turb-comp }\end{array}$ & $20-25 \%$ & - & Development \\
\hline $\begin{array}{l}\text { Compression ignition DI } \\
\text { gasoline }\end{array}$ & $15-25 \%$ & Lean NOx, LT HC & Adv Eng \\
\hline 2-stroke opposed piston diesel & $25-35 \%$ & Lean NOx & Development \\
\hline
\end{tabular}

Fig. 3. Estimated $\mathrm{CO}_{2}$ emissions reductions, criteria pollutant issues, and status for representative LD engine technologies

The most efficient engine to ever reach the development stage is the 2-stroke opposed piston diesel engine. Independent modeling work [8] shows a $13-15 \%$ incremental fuel consumption reduction relative to a state-of-the-art 2020 diesel 1.2 liter engine, confirming earlier reports from developers [9].

Moving to HD engines, the US EPA Phase 2 HD GHG proposal [5] lists some potential engine technologies and implementation timing needed to meet the regulation. Figure 5 shows the projected technologies and GHG reductions for the largest truck engines. Technologies that will be implemented at the highest rate by 2024 are reducing friction and other parasitic losses, improved aftertreatment, reduced pumping losses, and improved combustion. The incremental hardware cost relative to 2017 levels associ- ated with these items is estimated by the EPA to be about \$400-500 at maturity.

To help move these engine technologies forward, the US Department of Energy SuperTruck Program is now closing [10]. Common features independently developed by each of the four program participants to achieve 50\% BTE engines (brake thermal efficiency = energy to crankshaft/energy in fuel) under road loads are:

- Engine efficiency: high efficiency turbochargers, friction reduction, reduced ancillary losses.

- Fuel Injection: high-pressure common rail.

- Combustion: higher compression ratio, optimized piston bowl redesign.

- Waste Heat Recovery: Rankine cycle.

- Selective Catalytic Reduction (SCR) for $\mathrm{NO}_{\mathrm{x}}$ : higher efficiency deNOx, low $\Delta \mathrm{P}$.

Although Rankine cycle waste heat recovery gives the largest fuel savings, and it was used by all four participants to achieve $50 \%$ BTE, the other technologies are enough in combination to achieve the program goals.

\begin{tabular}{|l|c|c|c|c|}
\hline $\begin{array}{l}\text { Supplemental } \\
\text { Emissions Test (SET) } \\
\text { Mode }\end{array}$ & $\begin{array}{c}\text { SET Weighted } \\
\text { Reduction (\%) } \\
(\mathbf{2 0 2 0 - 2 0 2 7 )}\end{array}$ & $\begin{array}{c}\text { Market } \\
\text { Penetration } \\
\text { (2021) }\end{array}$ & $\begin{array}{c}\text { Market } \\
\text { Penetration } \\
\text { (2024) }\end{array}$ & $\begin{array}{c}\text { Market } \\
\text { Penetration } \\
\text { (2027) }\end{array}$ \\
\hline $\begin{array}{l}\text { Turbo compound with } \\
\text { clutch }\end{array}$ & $1.8 \%$ & $5 \%$ & $10 \%$ & $10 \%$ \\
\hline WHR (Rankine cycle) & $3.6 \%$ & $1 \%$ & $5 \%$ & $15 \%$ \\
\hline $\begin{array}{l}\text { Parasitic/Friction (Cyl } \\
\text { kits, pumps, FIE), } \\
\text { lubrication }\end{array}$ & $1.4 \%$ & $45 \%$ & $95 \%$ & $100 \%$ \\
\hline $\begin{array}{l}\text { Aftertreatment (lower } \\
\text { dP) }\end{array}$ & $0.6 \%$ & $45 \%$ & $95 \%$ & $100 \%$ \\
\hline $\begin{array}{l}\text { EGR/Intake \& exhaust } \\
\text { manifolds/Turbo/VVT/ } \\
\text { Ports }\end{array}$ & $1.1 \%$ & $45 \%$ & $95 \%$ & $100 \%$ \\
\hline Combustion/FI/Control & $1.1 \%$ & $45 \%$ & $95 \%$ & $100 \%$ \\
\hline Downsizing & $0.3 \%$ & $10 \%$ & $20 \%$ & $30 \%$ \\
\hline $\begin{array}{l}\text { Weighted reduction } \\
\text { (\%) }\end{array}$ & & $1.5 \%$ & $3.7 \%$ & $4.2 \%$ \\
\hline
\end{tabular}

Fig. 5. Projected large truck engine fuel consumption reductions (relative to 2017 engines) [5]

\section{4. $\mathrm{NO}_{\mathrm{x}}$ control}

Light-duty diesel $\mathrm{NO}_{\mathrm{x}}$ control is being driven by the Euro 6 regulation $\left(80 \mathrm{mg} / \mathrm{km} \mathrm{NO}_{\mathrm{x}}\right.$ on the World-Harmonize Light-

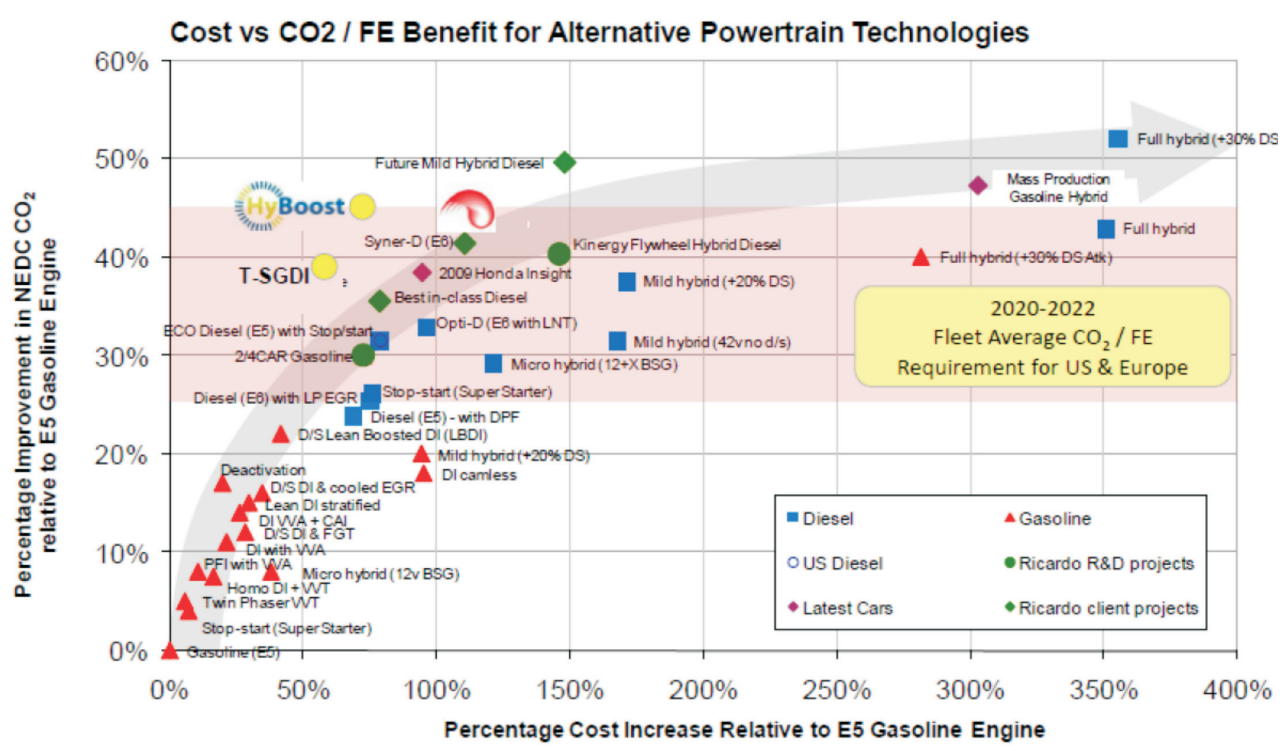

Fig. 4. Estimates of $\mathrm{CO}_{2}$ reductions and costs relative to a Euro 5 gasoline car [6]
Duty Test Cycle, WLTC), but the emerging RDE regulations are requiring even more $\mathrm{NO}_{\mathrm{x}}$ control, with conformity factors of $2.1 \mathrm{x}$ (multiple of the certification testing; $168 \mathrm{mg} / \mathrm{km}$ ) in September 2017 and $1.5 x$ $(120 \mathrm{mg} / \mathrm{km})$ in September 2020 for new engines. The current US regulations are about $50 \%$ tighter on a fleet average basis, but cars can certify higher as long as other cars (e.g., gasoline) certify lower than the average. The emerging US LD $\mathrm{NO}_{x}$ regulations are about an order of magnitude lower than Euro 6. 
The leading $\mathrm{NO}_{\mathrm{x}}$ architecture for both LD markets is the $\mathrm{NO}_{\mathrm{x}}$ storage catalyst (NSC) followed by an SCR catalyst either coated on a diesel particulate filter (DPF) or downstream from it, or both [11]. The NSC has good low-temperature performance, and generates $\mathrm{NH}_{3}$ during the rich desorption portion of the operating cycle, to replace or supplement urea injection to the SCR catalyst. Figure 6 shows some of the architectures [12]. Using only the $\mathrm{NH}_{3}$ coming from the NSC, a "passively" operated NSC+SCR system (no urea) reduces $\mathrm{NO}_{\mathrm{x}}$ nearly $80 \%$ on the WLTC, with all the cold start $\mathrm{NO}_{x}$ reductions coming from the NSC, and only $7 \%$ of the total reductions coming from the SCR unit. Larger cars or higher-load operation may require urea as an addition $\mathrm{NH}_{3}$ source. With urea-based NSC+SCR systems, upwards of $90-95 \%$ cycle averaged deNOx efficiencies can be achieved. In city driving cycles the NSC removes about 2/3rd of the treated $\mathrm{NO}_{x}$, with the urea-SCR taking up the remaining third. Even on a highway cycle, the $\mathrm{NO}_{x}$ burden is roughly evenly split between the NSC and SCR. For cold start applications, it is beneficial to locate the SCR catalyst as close to the engine as possible, so SCR catalyst coated onto the DPF is preferred.

Passive $\mathrm{NO}_{\mathrm{x}}$ adsorbers (PNA) release the $\mathrm{NO}_{\mathrm{x}}$ thermally $\left(\mathrm{T}>180^{\circ} \mathrm{C}\right.$ ) rather than chemically (rich-lean cycling). In one study [13], about $10 \%$ of the engine $\mathrm{NO}_{\mathrm{x}}$ was removed on the NEDC, all of it in the cold start portion, by the passive $\mathrm{NO}_{\mathrm{x}}$ adsorber and converted in the $\mathrm{SCR}$. $\mathrm{NO}_{\mathrm{x}}$ emissions are $25 \%$ lower than if a DOC (diesel oxidation catalyst) was used instead of the $\mathrm{NO}_{x}$ adsorber. Improvements are coming. When palladium is added to a ZSM-5 zeolite, $\mathrm{NO}_{\mathrm{x}}$ can be stored at $50^{\circ} \mathrm{C}$ and released at 250 $400^{\circ} \mathrm{C}[14]$. The zeolite also adsorbs hydrocarbons, and it is thought the released HCs help in $\mathrm{NO}_{\mathrm{x}}$ reduction.

In the heavy-duty sector, the aftertreatment architecture has been essentially unchanged since about 2010: DOC+ +DPF+SCR+ASC (ammonia slip catalyst). These systems are now achieving $>96 \%$ cycleaveraged deNOx efficiencies on the cold and hot start composite transient cycles. However, to meet the future California HD low- $\mathrm{NO}_{\mathrm{x}}$ regulations that are being discussed with minimized GHG impacts, $>99 \%$ deNOx efficiency will be needed. In an

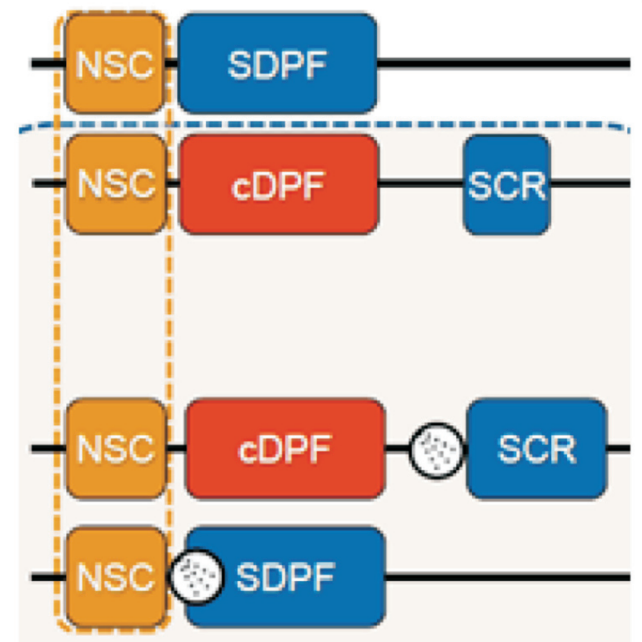

Fig. 6. Some of the LDD aftertreatment system designs for Euro 6c (RDE) [12]

interim report of a technical feasibility study, $20 \mathrm{mg} / \mathrm{bhp}-\mathrm{hr}$ $\mathrm{NO}_{x}$ was achieved in composite (cold plus hot start) US HD transient testing using a burner rig simulator of engine exhaust conditions [15]. Technologies employed included improved engine calibration, auxiliary heating during the cold start and low-load periods, PNA, SCR+DPF, heated
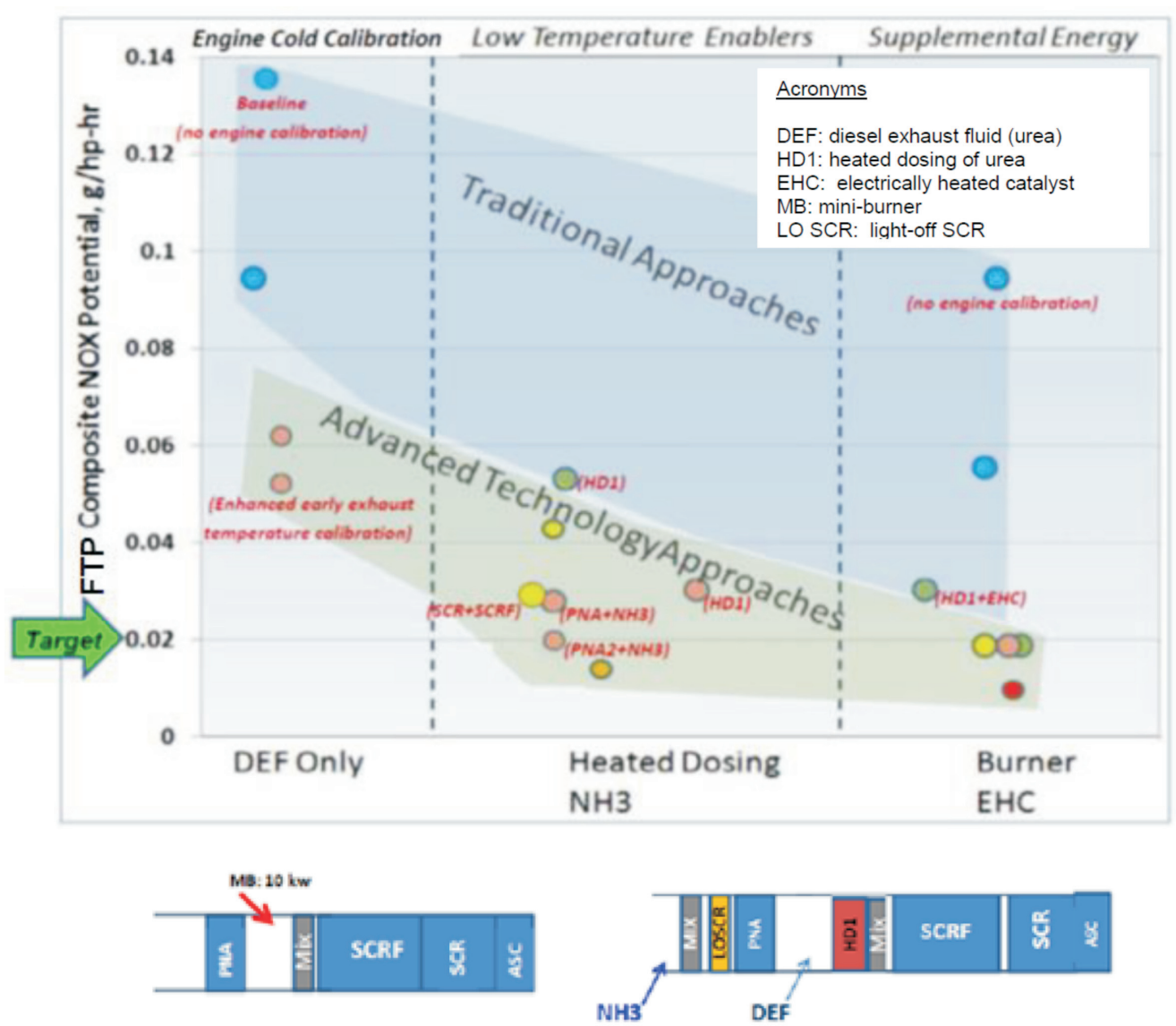

Fig. 7. Preliminary burner rig results and two HD systems delivering the lowest $\mathrm{NO}_{\mathrm{x}}[15]$ 
urea or gaseous $\mathrm{NH}_{3}$ injection, more SCR volume, and/or a light-off SCR catalyst. Figure 7 shows some results and the two lowest-configurations with the lowest $\mathrm{NO}_{\mathrm{x}}$.

\section{Oxidation catalysts}

Diesel oxidation catalysts (DOCs) play the role of pre-conditioning the exhaust for the complex downstream components. As such, DOCs are being designed for specific applications. Fundamentals are still being developed.

DOC formulations balance the palladium and platinum levels for optimum performance. The precious metal ratio, hydrocarbon and $\mathrm{CO}$ oxidation characteristics, and $\mathrm{NO}_{2}$ formation were simultaneously simulated and tested in a light-duty DOC [16]. They looked at the LD application with a constant PGM (platinum group metals) loading of $4.2 \mathrm{~g} /$ liter $\left(120 \mathrm{~g} / \mathrm{ft}^{3}\right)$. Increased platinum content improves n- $\mathrm{C}_{10} \mathrm{H}_{22}$, lean $\mathrm{C}_{3} \mathrm{H}_{6}$, and $\mathrm{CO}$ oxidation (except $100 \% \mathrm{Pt}$ ); but also NO oxidation, and the reduction back to NO by $\mathrm{C}_{3} \mathrm{H}_{6}$ and $\mathrm{CO}$. Conversely, reactions promoted by increasing or pure palladium are $\mathrm{CO}$ and methane oxidation, $\mathrm{C}_{3} \mathrm{H}_{6}$ steam reforming, and rich $\mathrm{C}_{3} \mathrm{H}_{6}$ oxidation. A similar study [17] looked at HD applications. The results show a strong dependence of the NO oxidation on the catalyst oxidation state for different Pt-Pd DOCs. A model was developed and a case study demonstrated the capabilities of the model in designing an appropriate DOC for a given application.

Methane oxidation is important for natural gas engines, and can limit the application of these engines in Europe due to regulatory limits of $160 \mathrm{mg} / \mathrm{kWh}$ total $\mathrm{HC}$ on the transient cycle for compression ignition, and $500 \mathrm{mg} / \mathrm{kWh}$ methane for spark ignition engines. Methane is difficult to oxidize and the best commercial catalysts need $\mathrm{T}>350^{\circ} \mathrm{C}$ to convert $50 \%$ of the methane. However, it was recently reported [18] that a platinum-palladium catalyst on a titania and ZSM-5 zeolite support that dropped this temperature to $<250^{\circ} \mathrm{C}$.

\section{Gasoline particulate filters}

Converse to the US, the European Union has implemented a particle number (PN) standard for gasoline direct injection engines, $6 \mathrm{E} 12$ particles $/ \mathrm{km}$, tightening to $6 \mathrm{E} 11$ particles/km in 2017. In addition, the European Commission is likely to recommend maintaining these values in RDE testing, after taking into account measurement error. Improved fuel injection and other engine methods can be used to help meet these standards [19], but these methods can fail to meet the regulations as the engine ages, if engine deposits form [20], or if the car is driven in somewhat more aggressive drive cycles or is not warm [11]. Alternatively, gasoline particulate filters (GPFs) provide a robust solution. Further, poly-aromatic hydrocarbons may be strongly associated with the particles, and GFPs greatly reduce these [11]. Hence, GPFs are a leading technology being evaluated to meet the European and proposed Chinese PN regulations.

Earlier GPF work focused on bare filters, but high porosity filter substrates can make adding a three-way catalyst to the filter attractive [21]. Back pressure with a "four-way catalyst" is only $10 \%$ more than that of the base TWC system [22]. Engine performance impacts after $160,000 \mathrm{~km}$ is minimally affected [21], with only $2.5 \%$ loss of peak power and $<1 \%$ loss of peak torque, with no deterioration in fuel consumption.

Regarding filter regeneration, a GPF was preloaded with a representative soot surrogate and installed in the underfloor (UF) position on a car [23]. Figure 8 shows actual and simulated results. The soot is mainly burned during the lean decelerations. At $30 \mathrm{~km} / \mathrm{h}$ there was no soot burn, but nor was there soot accumulation. Also shown in the figure is a simulated case when the filter is in the close-coupled (CC) position. Soot burn is rapid due to the higher temperatures.

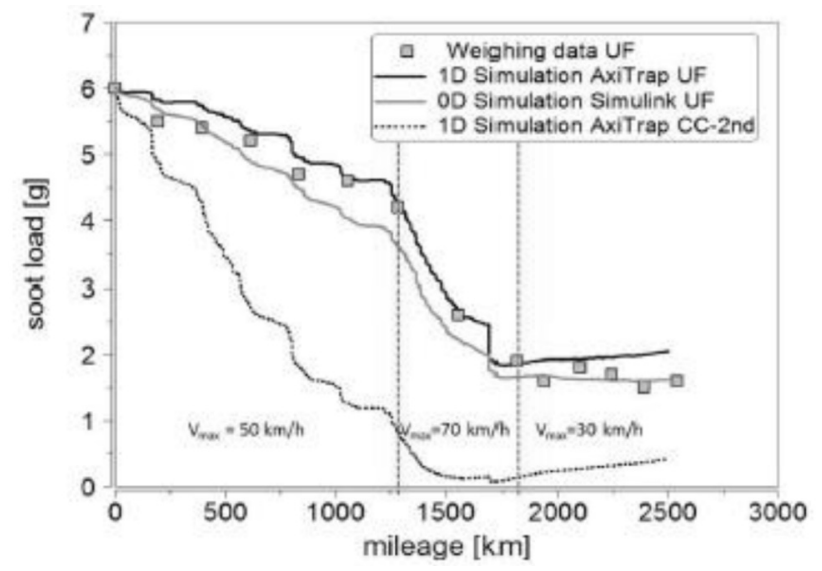

Fig. 8. Measured and simulated burning of soot in under-floor GPFs for three different average speed regimes [23]

\section{Conclusions}

The LD regulations in representative markets are compared. The emerging US Tier 3 regulations (starting in 2017) are about an order of magnitude tighter than the current Euro 6 regulations. Europe is shifting focus to real-world driving emissions (RDE) for LD diesel $\mathrm{NO}_{\mathrm{x}}$ and GDI (gasoline direct injection) PN (particle number) in 2017. China has been following the EU, but is proposing standards for 2023 that are $1 / 3$ of Euro 6. LD GHG (greenhouse gas) regulations are also compared, with Europe implementing the tightest regulations. However, real-world reductions in the EU are significantly less than indicated by the regulation.

Europe and US currently have similar HD regulations, but California will be tightening down on $\mathrm{NO}_{\mathrm{x}}$ beginning in about 2023-27. The US EPA Phase 2 HD greenhouse gas standards for 2021-27, calling for a nominal 4-6\% tightening on engine $\mathrm{CO}_{2}$ and $15-25 \%$ for the whole truck, depending on class.

Gasoline engines are developing rapidly, slowly closing the gap with diesel, but LDDs are making incremental gains that are very cost effective versus other options automakers have. Exhaust temperatures are decreasing as engine efficiency improves. There are numerous incremental strategies are being used on HD engines to approach or attain $50 \%$ BTE.

Leading lean $\mathrm{NO}_{\mathrm{x}}$ reductions for heavy- and light-duty diesel engines is generally reviewed. SCR filters are central to the LD for meeting the EU RDE and US Tier 3 regulations. LD systems are using $\mathrm{NO}_{\mathrm{x}}$ storage catalysts (NSCs) 
for cold start and downstream SCR systems on filters and/ or in traditional flow-through designs. Advanced prototype HD systems are being evaluated for meeting the California HD low-NO objectives. Some achieve $<20 \mathrm{mg} / \mathrm{bhp}-\mathrm{hr} \mathrm{NO}_{\mathrm{x}}$ on a simulated HD FTP transient cycle.

Understanding on diesel oxidation catalysts continues to evolve. LD and HD simulations enable proper design to meet a variety of needs. An experimental catalyst was reported that oxidizes methane at $\sim 250^{\circ} \mathrm{C}$, about $100^{\circ} \mathrm{C}$ lower than the best commercial catalysts.

Gasoline particulate filters (GPFs) are essentially needed to meet the Euro 6c and RDE regulations coming in 2017. Toxic PAH (polycyclic aromatic hydrocarbon) emissions are reported from GDI vehicles and reduced using GPFs. GPF regeneration is characterized. Almost all the required burning of soot occurs during lean decelerations. Soot levels on GPFs reach an equilibrium loading in urban driving.

\section{References}

[1] Vehicle Emissions Testing Programme. Presented to British Parliament by the Secretary of State for Transport, April 2016, Web ISBN 9781474131308, www.gov.uk/government/publications.

[2] www.theicct.org/blogs/staff/improving-conversions-betweenpassenger-vehicle-efficiency-standards.

[3] Tietge, U., Zacharof, N., Ligterink, N., Lambrecht, U. From Laboratory to Road: A 2015 Update of Official and "RealWorld" Fuel Consumption and $\mathrm{CO}_{2}$ Values for Passenger Cars in Europe. White paper by International Council on Clean Transportation, September 2015, www.TheICCT.org.

[4] Thomas, J. Vehicle Efficiency and Tractive Work: Rate of Change for the Past Decade and Accelerated Progress Required for U.S. Fuel Economy and $\mathrm{CO}_{2}$ Regulations. SAE Int. J. Fuels Lubr. 9(1):2016, doi:10.4271/2016-01-0909.

[5] Greenhouse Gas Emissions and Fuel Efficiency Standards for Medium- and Heavy-Duty Engines and Vehicles - Phase 2. www3.epa.gov/otaq/climate/documents/2016-08-ghg-hdfinal-rule-phase2-preamble.pdf.

[6] Kezerle, J.A. ADEPT 48 V Mild Hybridisation - 'Intelligent Electrification' The next step to HyBoost. Presentation at 8th Integer Emissions Summit and DEF Forum USA, October 2015.

[7] Pischinger, S. Current and Future Challenges for Automotive Catalysis Engine Technology Trends and their Impact. Presentation at Catalyst for Automotive Pollution Control 10 (CAPoC), Brussels, October 2015.

[8] Warey, A., Gopalakrishnan, V., Potter, M., Mattarelli, E. et al. An Analytical Assessment of the CO2 Emissions Benefit of Two-Stroke Diesel Engines. SAE Technical Paper 2016-010659, doi:10.4271/2016-01-0659.

[9] Redon, F. Advances in Opposed Piston Engine Performance and Emissions. Presentation at SAE High-Efficiency Engine Symposium, Detroit, April 2014.

Timothy V. Johnson, DEng. - Director of Emerging Technologies, Corning Incorporated.

e-mail:JohnsonTV@Corning.com
[10] National Academies of Sciences, Engineering, and Medicine. 2015. Review of the $21^{\text {st }}$ Century Truck Partnership, Third Report. Washington, DC: The National Academies Press.

[11] Johnson, T. Vehicular Emissions in Review. SAE Int. J. Engines 9(2):2016, doi:10.4271/2016-01-0919.

[12] Kreuz, J., Noack, H.-D., Welsch, F., Baron, J., Bremm, S. NSC and SCR As Components in a Modular System for Sustainable Solutions of Passenger Car Exhaust Aftertreatment. Presentation at Hyundai Kia International Power Train Conference 2015, Korea, October 27-28, 2015.

[13] Wylie, J. SCRF® Systems for Eu6c. Hyundai Kia International Power Train Conference 2015, Korea, October 27-28, 2015.

[14] Murata, Y., Morita, T., Wada, K., Ohno, H. NO Trap ThreeWay Catalyst (N-TWC) Concept: TWC with $\mathrm{NO}_{x}$ Adsorption Properties at Low Temperatures for Cold-Start Emission Control. SAE Int. J. Fuels Lubr. 8(2):2015, doi:10.4271/201501-1002.

[15] Yoon, S., Sharp, C., Webb, C., Collins, J. et al. Evaluating Technologies to Lower Nitrogen Oxide Emissions from Heavy-Duty Engines. $26^{\text {th }}$ CRC Real World Emissions Workshop, Newport Beach, CA, March 13-16, 2016.

[16] Etheridge, J., Watling, T., Izzard, A., Paterson, M. The Effect of Pt:Pd Ratio on Light-Duty Diesel Oxidation Catalyst Performance: An Experimental and Modelling Study. SAE Int. J. Engines 8(3):2015, doi:10.4271/2015-01-1053.

[17] Shakya, B., Sukumar, B., López-De Jesús, Y., Markatou, P. The Effect of Pt:Pd Ratio on Heavy-Duty Diesel Oxidation Catalyst Performance: An Experimental and Modeling Study. SAE Int. J. Engines 8(3):2015, doi:10.4271/2015-01-1052.

[18] Osman, A.I., Abu-Dahrieh, J.K., Laffir, F., Curtin, T. et al. A Bimetallic Catalyst on a Dual Component Support for Low Temperature Total Methane Oxidation. Applied Catalysis B: Environmental 187(2016):408-418, doi:10.1016/j. apcatb.2016.01.017.

[19] Pischinger, S. Current and Future Challenges for Automotive Catalysis Engine Technology Trends and their Impact. Presentation at Catalyst for Automotive Pollution Control 10 (CAPoC), Brussels, October 2015.

[20] Fraidl, G., Hollerer, P., Kapus, P., Ogris, M., Vidmar, K. Particulate Number for EU6+: Challenges and Solutions. Presentation at IQPC Advanced Emission Control Concepts for Gasoline Engines 2012, May 2012, Stuttgart.

[21] Joshi, A., Bronfenbrenner, D., Rose, D., Nicolin, P. et al. High Porosity Substrate and Filter Technologies for Advanced Gasoline Applications. $201515^{\text {th }}$ Hyundai-Kia International Powertrain Conference.

[22] Schmitz, T., Siemund, S., Siani, A., Neubauer, T., Burk, P., Gasoline Particulate Emission Reduction by Using Four Way Conversion Catalyst. Presentation at Hyundai Kia International Power Train Conference 2015, Korea, October 27-28, 2015.

[23] Nicolin, P., Rose, D., Kunath, F., Boger, T. Modeling of the Soot Oxidation in Gasoline Particulate Filters. SAE Int. J. Engines 8(3):2015, doi:10.4271/2015-01-1048.

Ameya Joshi, DEng.- Manager Emerging Technologies and Regulations, Corning Incorporated.

e-mail:JoshiA@Corning.com

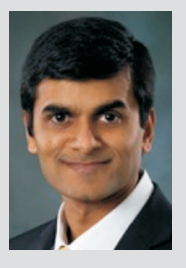

